\title{
Evaluation of Combustion of a Shredded Tobacco Bed Using a Reactor to Produce Reverse Smolder: Influence of Properties Related to Mass Transfer on Combustion of the Bed*
}

\author{
by \\ Atsushi Nagao ${ }^{1}$, Yoshiyuki Yamada ${ }^{l}$, Keigo Miura $^{l}$, and Masayuki Horio ${ }^{2}$ \\ ${ }^{1}$ Tobacco Science Research Center, Japan Tobacco Inc., 6-2, Umegaoka, Aoba-ku, Yokohama, Kanagawa 227-8512, Japan \\ ${ }^{2}$ Tokyo University of Agriculture and Technology, BASE, 2-24-16, Nakamachi, Koganei, Tokyo 184-8588, Japan
}

\section{SUMMARY}

The combustion mechanism of a shredded tobacco bed during puffing has been investigated. To evaluate changes in the burning rate of the shredded tobacco bed in the region close to the paper char-line, an experimental study was carried out on the reverse combustion of the shredded tobacco bed packed in a furnace. Measurements of the temperature in the shredded tobacco bed were conducted to calculate the combustion propagation rate. The combustion propagation rate decreased with an increase in the tobacco shred width, the tobacco packing density, and with a decrease in the air flow velocity. To investigate differences in the combustion propagation rate, the oxygen transfer coefficient of the shredded tobacco bed was evaluated using the effective diameter of the tobacco shred and the effective surface area of the shredded tobacco bed. The combustion propagation rate of the shredded tobacco bed increased with the oxygen transfer coefficient of the shredded tobacco bed. Furthermore, the weight loss of the cigarette during puffing was evaluated. The weight loss of the cigarette during puffing showed an increase with an increase in the oxygen transfer coefficient of the shredded tobacco bed. [Beitr. Tabakforsch. Int. 21 (2005) 350-357]

\section{ZUSAMMENFASSUNG}

Der Verbrennungsmechanismus einer Schicht aus zerkleinerten Tabakfasern während des Abrauchvorgangs wurde untersucht. Um die Veränderungen in der Abbrandgeschwindigkeit der Tabakfaserschicht in der Nähe der Brennlinie des Papiers abzuschätzen, wurde die umgekehrte Verbrennung der Tabakfaserschicht in einem Ofen experimentell untersucht. Es wurden Temperaturmessungen der Tabakfaserschicht durchgeführt, um die Geschwindigkeit der Ausbreitung des Abbrennvorgangs berechnen zu können. Die Geschwindigkeit der Ausbreitung des Abbrennvorgangs verringerte sich bei Zunahme der Schnittbreite der Tabakfasern, der Packungsdichte sowie bei abnehmender Geschwindigkeit des Luftstroms. Um die Unterschiede bei der Ausbreitung des Abbrennvorgangs zu untersuchen, wurde der Koeffizient des Sauerstofftransfers auf der Basis des Durchmessers der Tabakfasern und der Oberfläche der Schicht aus Tabakfasern berechnet. Die Geschwindigkeit, mit der die Schicht aus Tabakfasern abbrannte, nahm mit der Zunahme des Koeffizienten des Sauerstofftransfers der Tabakfaserschicht zu. Außerdem wurde der Gewichtsverlust einer Zigarette während des Abrauchens bestimmt. Der Gewichtsverlust einer Zigarette während des Abrauchens nahm mit Zunahme der Koeffizienten des Sauerstofftransfers der Tabakfaserschicht zu. [Beitr. Tabakforsch. Int. (2005) 350-357]

\section{RESUME}

Le mécanisme de combustion d'un lit de tabac haché au cours des bouffées a été examiné. Pour évaluer des changements de la vitesse de combustion du lit de tabac haché dans la région proche de la ligne de combustion, un essai sur la combustion inversée d'un lit de tabac haché chargé dans un four a été mené. Des mesures de la température du lit de tabac haché ont été conduites pour calculer la vitesse de propagation de la combustion. La vitesse de propagation de la combustion diminue en fonction d'une augmentation de la largeur des brins de tabac, la densité d'emballage du tabac et la diminution de la vitesse du flux d'air. Pour examiner les différences dans la vitesse de propagation de la combustion, le coefficient de transfert de l'oxygène du lit de tabac haché a été évalué, en se basant sur le diamètre effectif des brins de tabac et la surface effective du lit de 


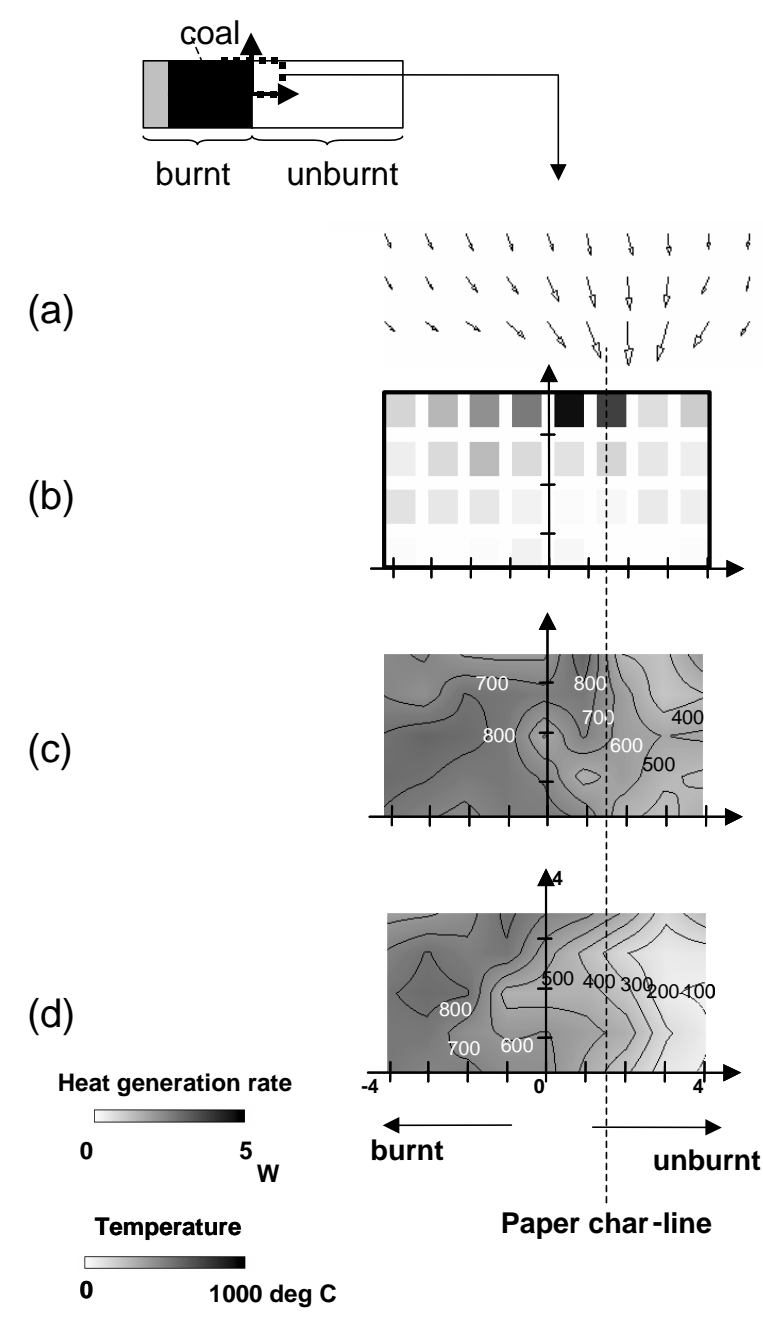

Figure 1. (a) Air flow distributions outside the burning cigarette (from reference (5); (b) heat generation rate distribution inside the cigarette (5); (c) solid-phase temperature distribution inside the cigarette during puffing (5); (d) gasphase temperature distribution inside the cigarette during puffing (5)

tabac haché. La vitesse de propagation de la combustion du lit de tabac augmente en fonction du coefficient de transfert de l'oxygène du lit de tabac haché. De plus, la perte de poids d'une cigarette au cours des bouffées a été évaluée. La perte de poids d'une cigarette au cours des bouffées augmente en fonction du coefficient de transfert d'oxygène du lit de tabac haché. [Beitr. Tabakforsch. Int. 21 (2005) 350-357]

\section{INTRODUCTION}

The cigarette combustion mechanism during puffing has been investigated and its details have been clarified over the past decades. BAKER reported the solid- and gas-phase temperature profiles inside a burning cigarette during puffing (1). He found that the maximum burning rate of the shredded tobacco bed was located behind the paper char-line during puffing. From the difference between the solid- and gas-phase temperature distributions, he deduced that the air was flowing into the tobacco bed close to the paper charline. He also obtained the air flow pattern and the rate of the air flow around the cigarette coal from the pressure distribution and the gas temperature distribution inside the burning cigarette using Darcy's Law and found that air enters through the paper char-line during puffing $(2,3)$. In a further study, BAKER also showed that above $400{ }^{\circ} \mathrm{C}$ the mass transfer of oxygen to the tobacco surface controls the tobacco combustion rate (4).

To investigate details of the air inflow position into the burning cigarette and the flow rate outside the cigarette, we measured the transient change of the flow rate distribution outside the burning cigarette during puffing directly using the Particle Image Velocimetry system (5). We also estimated the net heat generation rate at various positions inside the burning cigarette during puffing by calculation from the heat balance equations using the experimental temperature profiles (6). Figure 1 shows the distribution of the flow rate outside the burning cigarette, the heat generation rate, and the solid- and gas-phase temperatures inside the burning cigarette during puffing. It was found that the air mostly enters through a region close to the paper charline during puffing and most of the heat was generated in this region close to the paper char-line during puffing, as deduced by BAKER $(2,3)$. This indicates that the burning rate of the cigarette paper during puffing plays an important role in determining the burning region of the cigarette. We also showed that the heat generation rate near the paper char-line and the yields of the cigarette mainstream 'tar' and carbon oxides generated during puffing increase as the burning rate of the cigarette paper increases $(6,7)$. Therefore, the burning rate of the tobacco bed near the paper char-line during puffing should affect the total burning rate of the cigarette. Thus, it is important to analyze the burning propagation of the tobacco bed near the paper char-line. On the other hand, the shape of the tobacco shreds also affected cigarette combustion. SPEARS reported the effects of the tobacco shred width on the cigarette mainstream smoke (8). He found that carbon monoxide, carbon dioxide, 'tar' and nicotine decreased as the width increased. This indicates that the burning rate of the cigarette could be affected by the properties of the shredded tobacco bed related to the heat and/or mass transfers near the paper char-line.

In order to produce a better understanding of the tobacco bed near the paper char-line during puffing, a combustion reactor packed with tobacco shreds under steady conditions can be used to produce an approximate one-dimensional smolder combustion process. This permits an analysis of the combustion of the tobacco bed more simply by eliminating the effect of the cigarette paper on cigarette combustion. Smoldering is normally defined as propagation in two distinct modes, forward and reverse smolder $(9,10)$. In forward smolder, the reaction zone moves in the same direction as the oxidizer flow, while in reverse smolder, it moves in the opposite direction (10). In forward smolder, the incoming oxygen encounters hot char, becomes heated by passing through it, and then is consumed by reacting with combustionable material in the char. Oxygen in the incoming gas is depleted in the char oxidation zone before the combustion front reaches the pyrolysis zone. Therefore, the burning propagation rate of the bed is controlled by the fact that the incoming oxygen first encounters hot char and apparently cannot penetrate this zone without total consumption. This means that the burning propagation rate of 

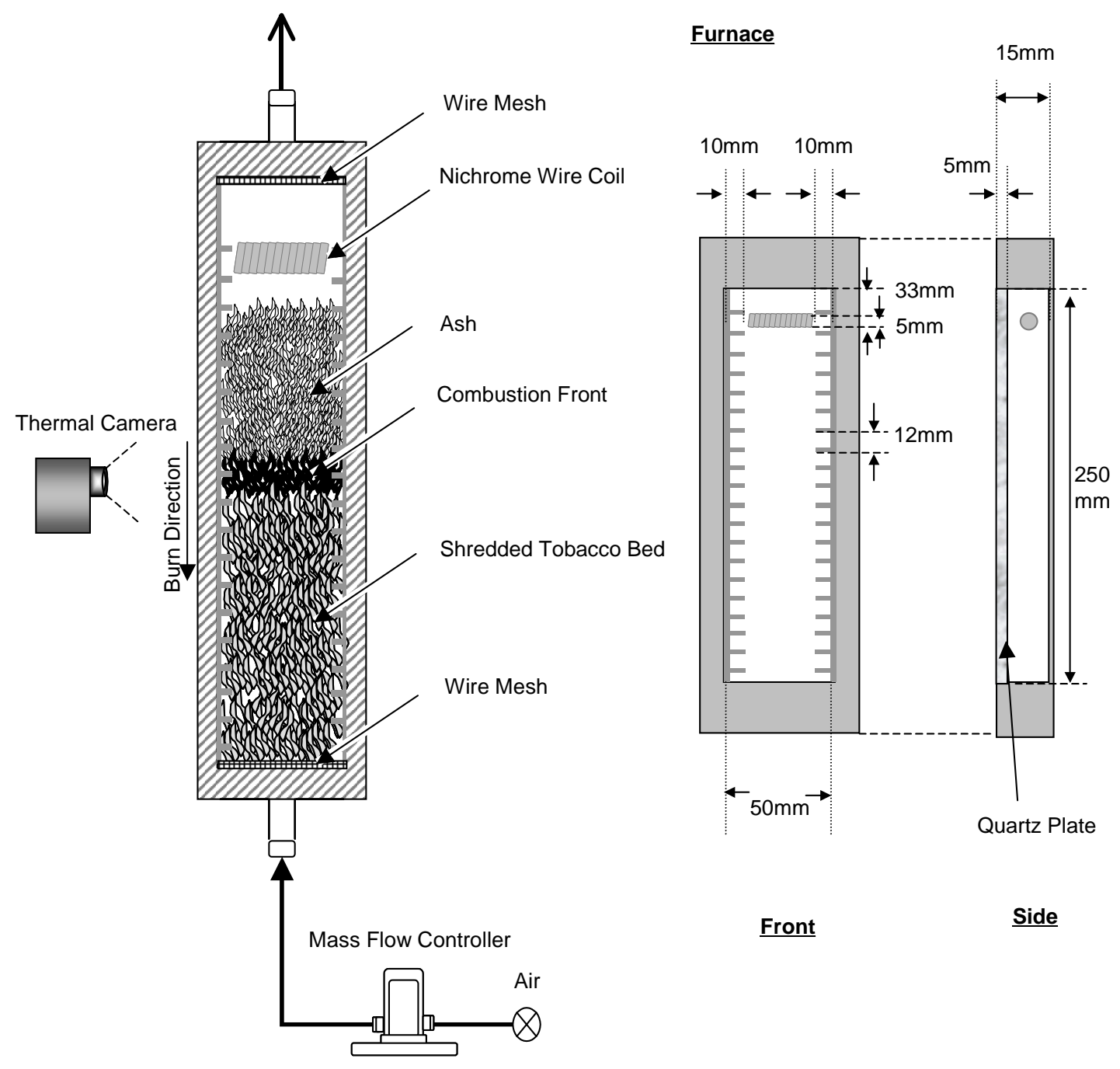

Figure 2. Schematic diagram of experimental apparatus and furnace

the bed is determined by the fuel density and the amount of oxygen supplied to the char oxidation reaction zone, and it is independent of the heat and mass transfer in the nonburning and pyrolysis zones. On the other hand, in reverse combustion, oxygen in the carrier gas is not depleted completely before the gas reaches the combustion front. Many reports provide data concerning the reverse combustion process in the packed bed of various combustionable materials, such as wood, activated carbon, polyurethane, and paper (9-14). The burning propagation rate for the reverse combustion is affected by the properties of the combustion front related to the heat and mass transfer $(13,14)$. Although cigarette combustion is a typical example of the forward smolder, the cigarette combustion takes place under the unsteady condition of two or three-dimensional smolder propagation. The cigarette during puffing mainly burns in the region close to the paper char-line and sufficient air is transported into that region. This means that sufficient air is supplied to the combustion front of the cigarette during puffing. Furthermore, as shown by SPEARS (8), the properties of the tobacco bed related to the heat and/or mass transfer could affect the burning rate of the cigarette during puffing. Even though the reverse combustion process has little direct relevance to the cigarette during puffing, the data concerning the reverse combustion should help us under- stand the combustion process in the region close to the paper char-line during puffing.

To generate knowledge of the combustion mechanism of the tobacco bed near the paper char-line during puffing, an experimental study has been carried out on the combustion of the shredded tobacco bed under conditions that produce the reverse combustion process. We focused on the effect of the air flow velocity, the tobacco shred width, and the tobacco packing density on the tobacco burning rate in reverse combustion. We also introduced the oxygen transfer coefficient of the shredded tobacco bed and investigated the relationship between the coefficient and the combustion propagation rate. Furthermore, we evaluated the weight loss of the cigarette during puffing and investigated the effects of the oxygen transfer coefficient of the shredded tobacco bed on the weight loss of the cigarette during puffing.

\section{EXPERIMENTAL}

\section{Reverse combustion process of the shredded tobacco bed}

Figure 2 shows a schematic diagram of the experimental apparatus for the reverse combustion of the shredded tobacco bed. The furnace was made of stainless steel. In the 


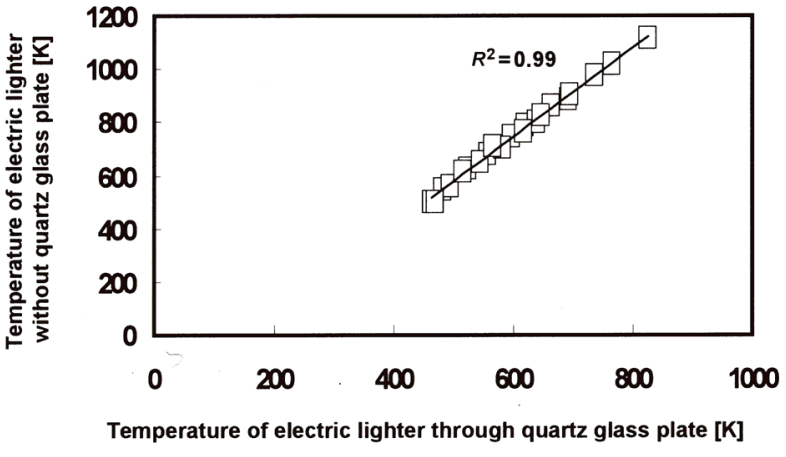

Figure 3. A comparison of the electric lighter temperature through the quartz glass plate with the actual temperature

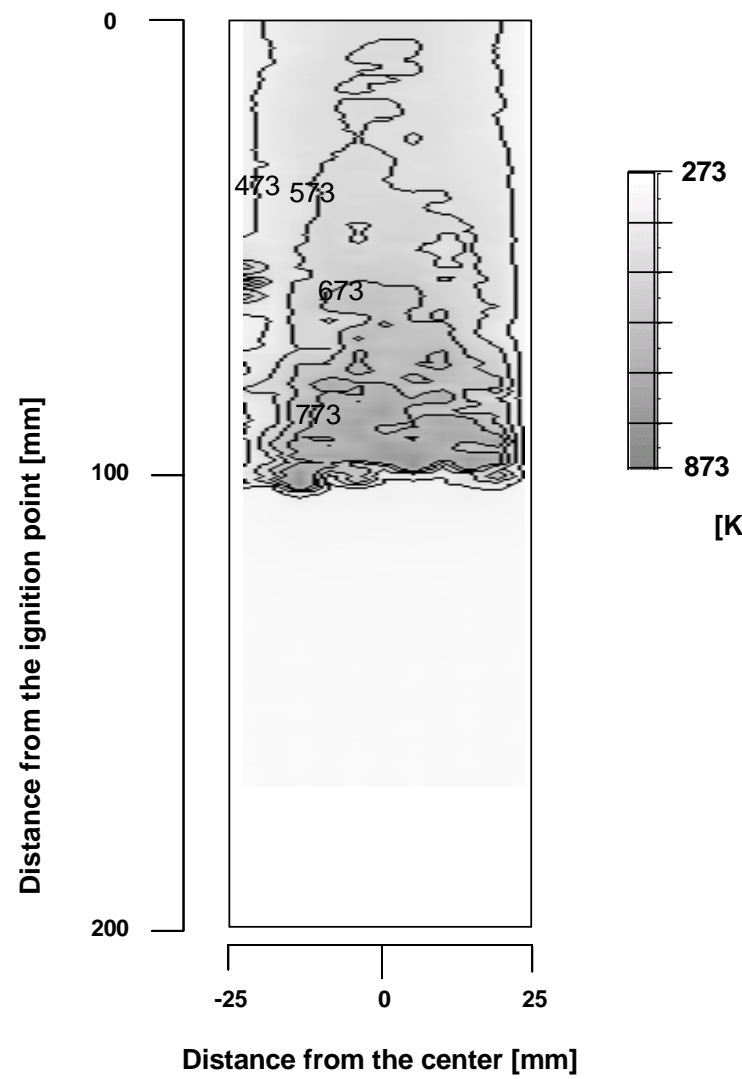

Figure 4. Temperature distribution inside a cigarette when the combustion front reached the $100 \mathrm{~mm}$ mark after ignition with air flow of $0.22 \mathrm{~m} / \mathrm{s}$

front of the test section, a quartz glass plate was set in order to observe the combustion propagation using a thermal camera (TVS-8500, Nippon Avionics Co.,Ltd.), which was used to measure the temperature distribution. In this study, it is assumed that the thermal camera measures the solidphase temperature. The furnace was placed in the vertical direction. Air was used as oxidizer and flowed into the tobacco bed in the opposite direction of the combustion propagation. The flow velocity was adjusted by the mass flow meter to be between 0 and $0.56 \mathrm{~m} / \mathrm{s}$. To avoid a flow drift into the side of the test section where the tobacco packing density might be poor, a shading plate was placed on the side of the test section.

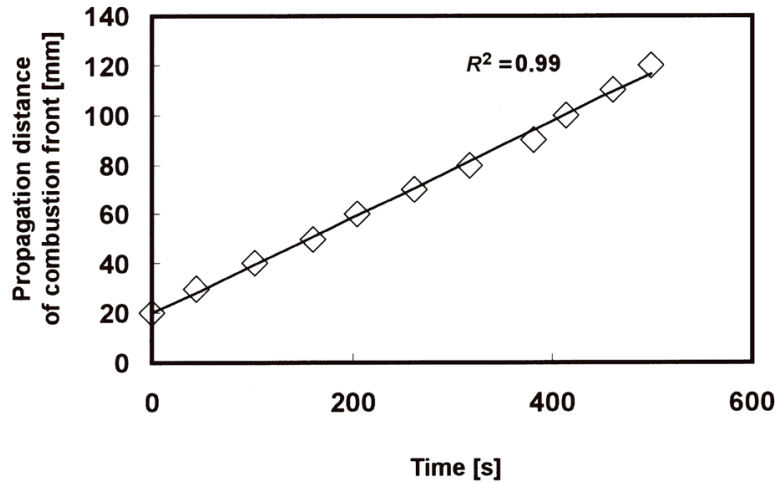

Figure 5. The combustion propagation distance of the shredded tobacco bed as a function of the time after the front reaches $20 \mathrm{~mm}$ from the ignition point

The tobacco bed temperature that is measured through the quartz glass plate is lower than the actual temperature because of the absorption of infrared radiation by the quartz glass plate. In preliminary experiments, an electric lighter (Electric lighter; Borgwaldt $\mathrm{GmbH}$ ) was used in order to set the measured temperature of the shredded tobacco bed through the quartz glass plate to the actual temperature. Figure 3 shows the results of a comparison of the temperature of the electric lighter through the quartz glass plate with the temperature without the plate. The temperature through the quartz glass plate showed a linear relationship to the temperature without the quartz plate as shown in Figure 3. Figure 4 shows an example of the temperature distribution of the shredded tobacco bed (tobacco packing density $1.5 \times 10^{5} \mathrm{~g} / \mathrm{m}^{3}$, tobacco shred width $1.0 \mathrm{~mm}$, air flow velocity $0.22 \mathrm{~m} / \mathrm{s}$ ). From BALIGA's data, the tobacco begins to char at approximately $573 \mathrm{~K}$ (15). The $573 \mathrm{~K}$ line located at the lowest position was defined as the combustion front in this study. The combustion front was perpendicular to the propagation direction in this study. The movement rate of the combustion front at the center of the combustion front was evaluated as the combustion propagation rate of the shredded tobacco bed. Figure 5 shows the combustion front position of the shredded tobacco bed as a function of the time after the front reaches the $20 \mathrm{~mm}$ position from the ignition point. The lighter was set at $1073 \mathrm{~K}$ and it was used to heat the tobacco for $15 \mathrm{~s}$. After ignition, it was found to be confirmed that the tobacco bed smoldered for all samples and conditions. The time was in proportion to the combustion propagation distance from the $20 \mathrm{~mm}$ position in this study. The combustion propagation rates of the shredded tobacco bed were calculated from the combustion propagation distances between the 20 and $500 \mathrm{~mm}$ positions.

The design specifications of the tobacco shred width and the tobacco packing density are shown in Table 1. Samples 1 to 5 consisted of the same American tobacco blend, which is a mixture of flue-cured and burley tobacco.

\section{Experimental procedure for weight loss of the cigarette during puffing}

The weight losses of the cigarettes during puffing were obtained by measuring the differences in the weight of the cigarette before and after puffing. Figure 6 shows the 
Table 1. Design specifications of tobacco shred and tobacco bed

\begin{tabular}{|l|l|l}
\hline Sample & Cutting width $[\mathrm{mm}]$ & Tobacco bed density $\times 10^{5}\left[\mathrm{~g} / \mathrm{m}^{3}\right]$ \\
\hline
\end{tabular}

\begin{tabular}{lll}
1 & 1.0 & 1.5 \\
2 & 1.0 & 2.3 \\
3 & 1.0 & 2.7 \\
4 & 0.5 & 2.3 \\
5 & 1.5 & 2.3 \\
\hline
\end{tabular}

procedure for measuring the weight loss. In order to eliminate the filtration of the mainstream smoke by the shredded tobacco bed as far as possible, a cigarette as short as possible was used. The sample cigarettes were $8 \mathrm{~mm}$ in diameter. The inside of the filter cavity used was empty. Experimental cigarettes were wrapped in the same cigarette paper. The permeability of the cigarette paper used was 35 CORESTA units (CU). The shredded tobacco beds as shown in Table 1 were used.

\section{RESULTS AND DISCUSSION}

\section{Reverse combustion process of shredded tobacco bed}

Figure 7 shows the combustion propagation rate as a function of the flow velocity for various packing densities of the shredded tobacco bed. The linear burning rate is shown in Figure $7 \mathrm{a}$, and the mass burning rate is shown in Figure $7 \mathrm{~b}$. The mass burning rate was obtained by multiplying the tobacco weight per unit length by the linear burning rate. The linear burning rate increased with the air flow velocity. When the tobacco density increased, the linear burning rate decreased. No significant difference in the mass burning rate was observed between samples.

Figure 8 shows the combustion propagation rate as a function of the air flow velocity for the various widths of the tobacco shreds. With air velocities between 0 and $0.23 \mathrm{~m} / \mathrm{s}$, sample 5 did not ignite. When the tobacco shred width decreased, the mass burning rate increased. (a)

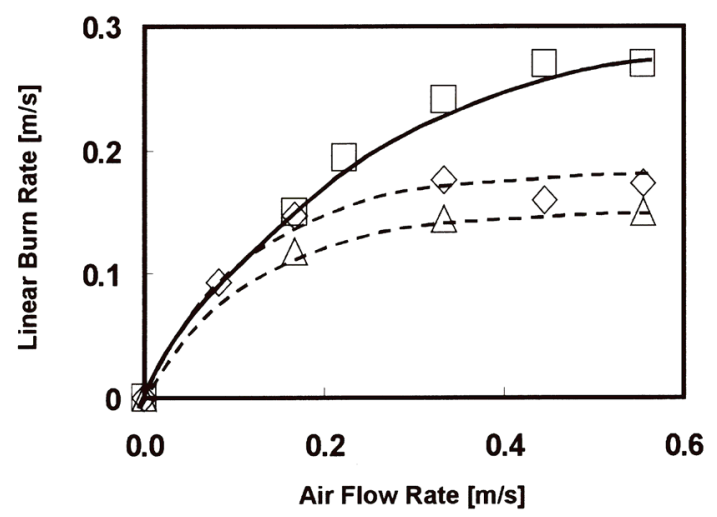

(b)

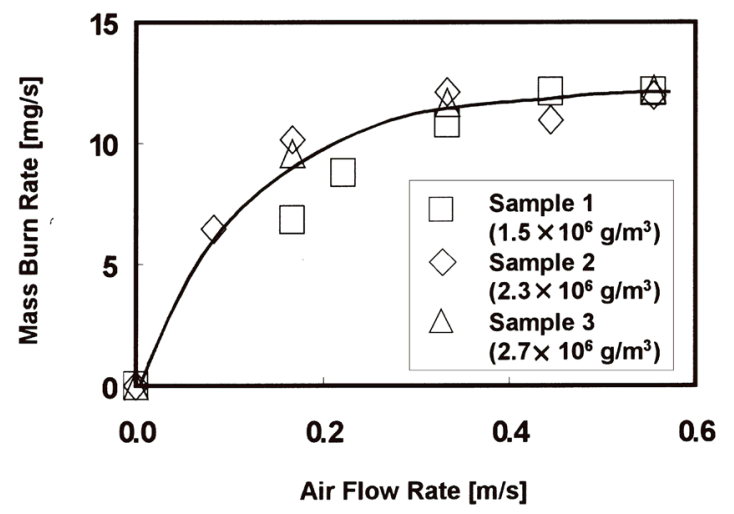

Figure 7. Linear burning rate (a) and mass burning rate (b) at three tobacco bed densities as a function of air flow

YAMADA et al. found that when the effective specific surface area of a packed bed of paper increases for the reverse combustion process, the combustion propagation rate increases (14). In this study, we investigated the relationship between the combustion propagation rate and the oxygen transfer coefficient of the shredded tobacco bed using the effective diameter of the tobacco shred and the effective surface area of the shredded tobacco bed.

(Cigarette Sample)

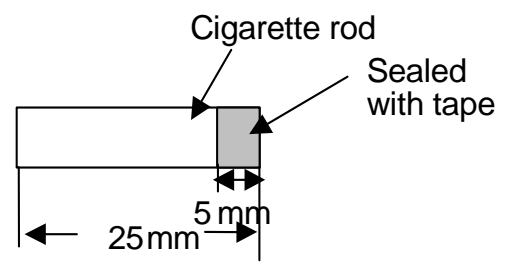

(Measurement of weight loss)

Before puffing

Extinguish cigarette

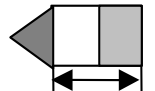

$10 \mathrm{~mm}$

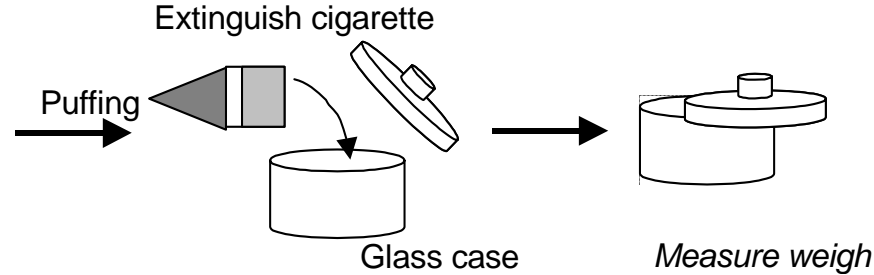

Measure weight

Figure 6. Procedure to measure the weight loss of cigarettes during a puff 


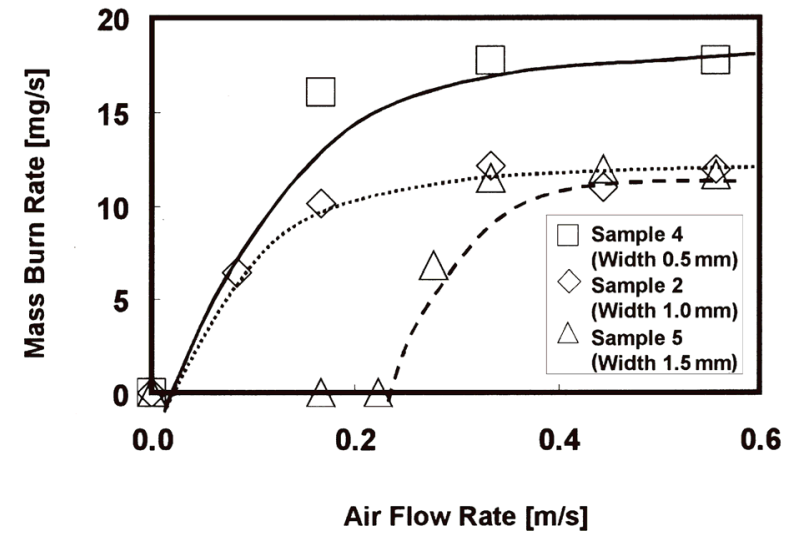

Figure 8. Mass burning rate at three tobacco shred widths as a function of air velocity

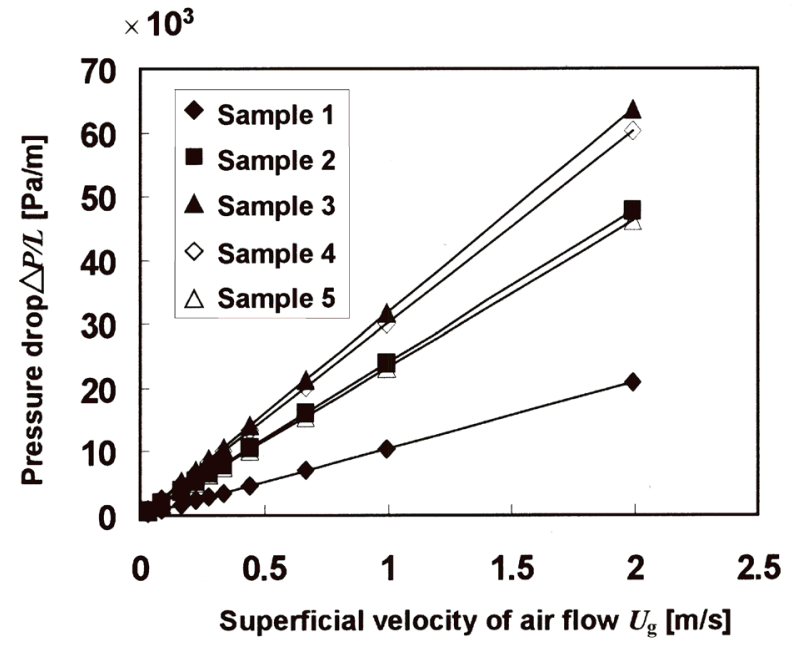

Figure 9. Pressure drop $\Delta P$ of tobacco bed as a function of superficial air flow velocity $U_{\mathrm{g}}$

The effective diameter and the effective specific surface area were obtained from Okada's results (16). The pressure drop of the shredded tobacco bed as a function of the superficial air flow velocity was measured. Using the experimental pressure drop values as shown in Figure 9, the effective diameter and the effective specific surface area were calculated from the following equations (16):

$$
\begin{gathered}
\frac{\Delta P}{L}=\kappa\left(150 \frac{(1-\varepsilon)^{2} \mu U_{\mathrm{g}}}{\varepsilon^{3} D_{\mathrm{p}}^{2}}+1.75 \frac{(1-\varepsilon) \rho_{\mathrm{a}} U_{\mathrm{g}}^{2}}{D_{\mathrm{p}} \varepsilon^{3}}\right) \\
S_{\mathrm{v}}=\frac{6(1-\varepsilon)}{D_{\mathrm{p}}}
\end{gathered}
$$

where $D_{\mathrm{p}}[\mathrm{m}]$ is the effective diameter, $S_{\mathrm{v}}[1 / \mathrm{m}]$ is the effective specific surface area, $L[\mathrm{~m}]$ is tobacco bed length, $\Delta P[\mathrm{~Pa}]$ is the experimental pressure drop, $\kappa$ is the shape factor, $U_{\mathrm{g}}[\mathrm{m} / \mathrm{s}]$ is superficial air flow velocity, $\varepsilon[-]$ is the space ratio of the tobacco bed, $\mu[\mathrm{kg} / \mathrm{m} / \mathrm{s}]$ is the air viscosity and $p_{\mathrm{a}}\left[\mathrm{kg} / \mathrm{m}^{3}\right]$ is the air density. Values of $D_{\mathrm{p}}$ and $S_{\mathrm{v}}$ are shown in Table 2. $D_{\mathrm{p}}$ and $S_{\mathrm{v}}$ increased as the tobacco packing density increased. An increase of $D_{\mathrm{p}}$ with the pa-
Table 2. Effective diameter $D_{\mathrm{p}}$ and effective specific surface area $S_{\mathrm{v}}$ of tobacco beds

\begin{tabular}{ll|l}
\hline Sample & $D_{\mathrm{p}}[\mathrm{m}]$ & $S_{\mathrm{v}}\left[\mathrm{m}^{2} / \mathrm{m}^{3}\right]$ \\
\hline 1 & $1.8 \times 10^{-4}$ & $6.6 \times 10^{3}$ \\
2 & $2.0 \times 10^{-4}$ & $8.3 \times 10^{3}$ \\
3 & $2.2 \times 10^{-4}$ & $8.4 \times 10^{3}$ \\
4 & $1.7 \times 10^{-4}$ & $9.5 \times 10^{3}$ \\
5 & $2.0 \times 10^{-4}$ & $8.2 \times 10^{3}$ \\
\hline
\end{tabular}

Table 3. Oxygen transfer coefficient $k\left[1 / \mathrm{s} \times 10^{4}\right]$ of the shredded tobacco bed of samples 1 to 5 for air flow rates of $0.2,0.4$ and $0.6 \mathrm{~m} / \mathrm{s}$

\begin{tabular}{l|c|c|c}
\hline \multirow{2}{*}{ Sample } & \multicolumn{3}{|c}{ Flow rate in bed } \\
\cline { 2 - 4 } 1 & $0.6 \mathrm{~m} / \mathrm{s}$ & $0.4 \mathrm{~m} / \mathrm{s}$ & $0.2 \mathrm{~m} / \mathrm{s}$ \\
2 & 4.4 & 3.4 & 2.1 \\
3 & 5.7 & 4.3 & 2.7 \\
4 & 6.2 & 4.8 & 3.0 \\
5 & 7.4 & 5.6 & 3.5 \\
& 5.5 & 3.6 & 2.3 \\
\hline
\end{tabular}

cking density is due to a decrease in the space ratio. When the width of the tobacco shred increased, $D_{\mathrm{p}}$ decreased and $S_{\mathrm{v}}$ increased. This causes a decrease of the pressure drop of the shredded tobacco bed with an increase of the tobacco shred width.

PECTORIS et al. (17) caluculated the oxygen transfer coefficient of the packed bed as follows:

$$
\begin{gathered}
k=\frac{D S_{\mathrm{v}} \mathrm{Sh}}{D_{\mathrm{p}} \varepsilon} \\
\mathrm{Sh}=\frac{0.357}{\varepsilon} \mathrm{Re}^{2 / 3} \mathrm{Sc}^{1 / 3}
\end{gathered}
$$

where $k[1 / \mathrm{s}]$ is the oxygen transfer coefficient, $D\left[\mathrm{~m}^{2} / \mathrm{s}\right]$ is the Chapman-Enskog diffusivity of $\mathrm{N}_{2}-\mathrm{O}_{2}$ at $773 \mathrm{~K}, \mathrm{Re}[-]$ is Reynolds Number, Sc [-] is Schmidt number and Sh [-]) is Sherwood number. Using Eqns. [3] and [4], the oxidation transfer coefficient of the tobacco bed was obtained. Table 3 shows the oxygen transfer coefficient $k$ for air flow velocities of $0.2,0.4$ and $0.6 \mathrm{~m} / \mathrm{s}$. When the tobacco packing density increased and the width of the tobacco shred decreased, the oxygen transfer coefficient $k$ increased.

TORERO et al. and LEACH et al. have shown that the combustion propagation rate in the reverse combustion increased with increasing the flow velocity due to an increased oxygen supply, but as the air velocity increased further, the smolder reaction became weaker and eventually died out due to convective cooling $(11,12)$. This shows that the combustion propagation rate is influenced by properties related to the oxidation reaction rate of the packed bed and/or the heat transfer rate. Figure 10 shows the relationship between the mass burning rate and the oxygen transfer coefficient $k$ of the tobacco shredded bed. It was observed that the mass burning rate of the shredded tobacco increased with $k$. With the flow velocities used in this study, the burning rate did not show a decrease with an increase 


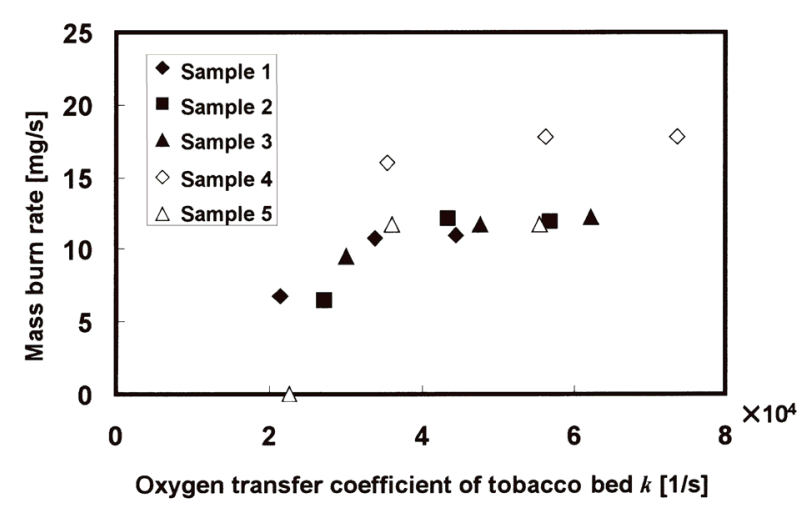

Figure 10. Relationship between the linear burning rate and the oxygen transfer coefficient of the shredded tobacco bed at air flow rates of $0.2,0.4$ and $0.6 \mathrm{~m} / \mathrm{s}$

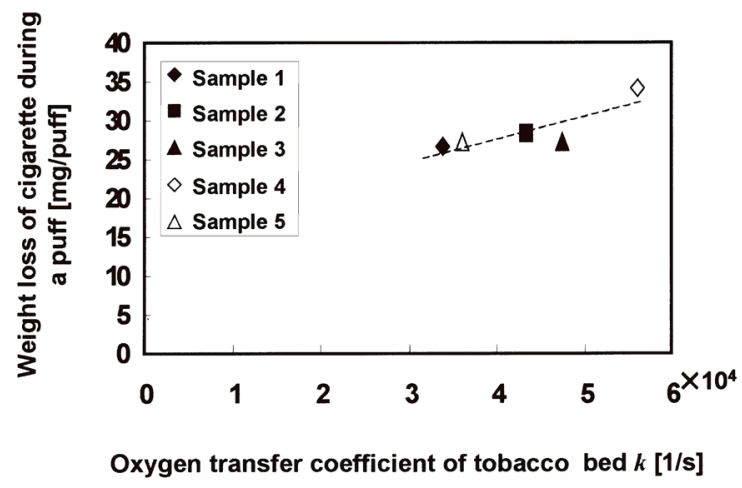

Figure 11. Relationship between the oxygen transfer coefficient of the shredded tobacco bed at air flow rate 0.4 $\mathrm{m} / \mathrm{s}$ and the weight loss of the cigarette during a puff

of the flow velocity. Based on papers (9) and (10), this result indicates that the oxidation reaction rate of the tobacco bed should be far larger than its heat transfer rate. Accordingly, the mass burning rate seemed to be strongly influenced by the oxidation reaction coefficient. On the other hand, the oxygen transfer coefficient is affected by $S_{\mathrm{v}}, D_{\mathrm{p}}, \varepsilon$ and flow velocity, as shown in Eqn. [3]. Therefore, these parameters should dominate the mass burning rate of the shredded tobacco bed.

\section{Effects of the mass transfer coefficient of the tobacco bed on the weight loss of cigarette during puffing}

In a previous report (6) it was found that most of the heat generation inside the burning cigarette during puffing occurred in the region close to the paper char-line where the air is mainly flowing into the burning tobacco bed. Therefore, it is presumed that the weight loss of the cigarette during puffing is related to the oxygen transfer coefficient of the shredded tobacco bed, which affects the propagation rate in the reverse combustion of the tobacco bed. Figure 11 shows the relationship between the weight loss of the cigarette during puffing and the oxygen transfer coefficient $k$ of the shredded tobacco bed. As shown by the results for the reverse combustion process in Figure 10, the weight loss of the tobacco bed increased with an increase of the oxygen transfer coefficient $k$ of the shredded tobacco bed.
Accordingly, the weight loss of the cigarette during puffing should be affected by the oxygen transfer coefficient of the shredded tobacco bed in the region close to the paper charline. Therefore, in the case of other tobacco shred types, such as expanded tobacco, stems, etc., if the constituent is the same, the width, packing ratio and the other parameters, such as the thickness of the tobacco, should affect the burning rate. These results, which indicate the importance of the oxygen transfer coefficient, are in agreement with the results of BAKER (4). These results showed that at temperatures above $400{ }^{\circ} \mathrm{C}$ the mass transfer of oxygen to the tobacco surface controls the tobacco combustion rate.

\section{CONCLUSIONS}

To evaluate the changes in the burning rate of the shredded tobacco bed, an experimental study has been carried out for the reverse combustion of the shredded tobacco bed with various packing densities and widths of tobacco shred. The linear burning rate decreased when the tobacco packing density and the tobacco shred width increased. The mass burning rate decreased with an increase in the tobacco shred width. The effective diameter and the effective specific surface area increased with an increase of the tobacco packing density and with a decrease of the tobacco shred width. When the oxygen transfer coefficient through the shredded tobacco bed increased, the mass burning rate increased. Also, the weight loss of the cigarette during puffing was evaluated. It was observed that the weight loss increased with the oxygen transfer coefficient. Accordingly, it was concluded that the weight loss of the cigarette during puffing should be affected by the oxygen transfer coefficient of the shredded tobacco bed in the region close to the paper char-line.

\section{REFERENCES}

1. Baker, R.R.: Temperature variation within a cigarette combustion coal during the smoking cycle; High Temp. Sci. 7 (1975) 236-247.

2. Baker, R.R.: Gas velocities inside a burning cigarette; Nature 264 (1976) 167-169.

3. Baker, R.R.: Contributions to the draw resistance of a burning cigarette; Beitr. Tabakforsch. Int. 8 (1975) 124-132.

4. Baker, R.R.: The kinetics of tobacco pyrolysis; Thermochim. Acta 17 (1976) 29-63.

5. Nagao, A., K. Miura, S. Kitao, and M. Horio: Measurement of air flow outside a burning cigarette during a puff using particle image velocimetry; Beitr. Tabakforsch. Int. 21 (2005) 216-222.

6. Nagao A., Y. Yamada, K. Miura, and M. Horio: A profile of the heat generation inside a cigarette during puffing; Beitr. Tabakforsch. Int. 21 (2005) 294-302.

7. Nagao, A., Y. Yamada, M. Tarora, and K. Miura: Burn rate of cigarette paper during a puff; 57th Tobacco Science Research Conference 2004, Norfolk, USA, 2003, Program Booklet and Abstracts No. 27.

8. Spears, A.W.: Effect of manufacturing variables on cigarette smoke composition; Proceedings of the 1978 
CORESTA Conference, Sofia, Bulgaria, 1978, pp. 65-78.

9. Ohlemiller, T.J.: Modeling of smoldering combustion propagation; Progress Energy Combust. Sci. 11 (1985) 227-310

10. Ohlemiller, T.J. and D.A. Lucca: An experimental comparison of forward and reverse smolder propagation in permeable fuel beds; Combust. Flame 54 (1983) 131-147.

11. Torero, J.L., A.C. Fernadez-Pello, and M.Kitano: Opposed forced flow smoldering of polyurethane foam; Combust. Sci. Tech. 91 (1993) 95-117.

12. Leach, S.V., J.L. Ellzey, and O.A.Ezekoye: A numerical study of reverse smoldering; Combust. Sci. Tech. 130 (1997) 247-267.

13. Shin, D. and S. Choi: The combustion of simulated waste particles in a fixed bed; Combust. Flame 121 (2000) 167-180.

14. Yamada, Y., K. Goto, and T. Nishimura: Effect of particle shape on reverse combustion process of packed bed; J. Chem. Eng. JAPAN 29 (2003) 500-506.
15. Baliga, V.L., D.E. Miser, R.K. Sharma, M.E. Thurston, W.G. Chan, and M.R. Hajaligol: Physical characterization of the cigarette coal: Part 1. Smolder burn; J. Anal. Appl. Pyro. 68-69 (2003) 443-465.

16. Okada, T., and K. Ota: On the draw resistance of a cigarette; Sci. Papers Centr. Res. Inst. Japan Tobacco Salt Public Corp. 117 (1975) 11-16.

17. Pectoris, J.L. and G. Thodos: Mass transfer in the flow of gases through packed beds; Indust. Engineer. Chem. Fundament. 7 (1968) 274-280.

\section{Corresponding author}

Tobacco Science Research Center, Japan Tobacco Inc., 6-2, Umegaoka, Aoba-ku, Yokohama, Kanagawa 227-8512, Japan

E-mail: atsushi.nagao@ims.jti.co.jp 